\title{
The Vote of Silence: The Problem of Abstention in Municipal Elections in Mozambique
}

\author{
Jochua Abrão Baloi \\ Faculty of Ethics, Human and Legal Sciences of the University of Saint Thomas of Mozambique, Maputo, \\ Mozambique. \\ Political Science PhD Candidate at the State University of Rio de Janeiro \\ jbaloi@yahoo.com.br
}

\begin{abstract}
This article analyzes the problem of absenteeism in the municipal elections in Mozambique, specifically analyzing Matola municipality in Maputo province. The central argument of this article is that the electoral absenteeism is a form of political questioning in order to demonstrate the dissatisfaction and protest of the electoral process per se. Most representative western democracies and Mozambique in particular, have experienced in recent times a higher percentage of abstention in electoral process. This phenomenon is due to the transformation of the way of understanding political participation through voting, which denotes the lack of political culture of elections. Therefore, it is concluded that in order to minimize the absenteeism in Matola municipality it is necessary to create a favorable institutional environment, where the citizens will feel the effect of their vote that guarantees them the exercise of citizenship.
\end{abstract}

Keywords : elections; abstentions; democracy; political participation.

\section{Introduction}

This article aims to analyze the problem of abstention in the municipal elections in Mozambique, taking as an analysis field, the Matola municipality, in Maputo Province. Thus, in all representative democracies, voting constitutes a conditio sine qua non for the political participation of citizens, in the sense that there is no other form of active participation in political life, which does not pass through the vote.

Therefore, free, fair and transparent elections are, until now, a thermometer to measure the functioning of a democratic political system at the level of the world, and not only, but they are also a key element in conferring legitimacy on the formation of governments.

In a democratic political system, voting is an element that contributes to the political participation of citizens, and electoral absenteeism can call into question for a democratic legitimacy, because high percentage indices of people do not appear in the polls to vote. This situation shows that only a limited proportion of the electorate actually participates in the democratic process.

The main question that guides this article is what are the reasons that justify the high rate of absenteeism in the municipal elections in Matola municipality? This question leads to the hypothesis that electoral absenteeism in Matola municipality is due to the lack of political culture of elections in Mozambique.

The methodological construction that guides this article involves a symbiosis of several methods (Qualitative, Monographic, Historical, Bibliographic), allying them to the hermeneutic-reflexive for the effective reach of the theoretical and historical referential of the problem of the autarchic electoral abstention in Matola municipality.

This paper is divided into four parts, in addition to this introduction and conclusion. In the first, there is a theoretical debate on the issue of electoral abstention and political participation in postmodernity. The second debate on the issue of absenteeism in autarchic elections in Mozambique, analyzing the case of Matola municipality. Then the causes that 
contribute to electoral absenteeism in Matola municipality are analyzed, and finally are presented the main challenges of electoral abstention in Matola municipality.

\section{Review of Literatures}

\subsection{Electoral Abstention and Political Participation in Post-Modernity}

In political science, the debate on electoral abstention and political participation is undoubtedly much broader than the question of electoral participation per se. There are latu sensu studies on the issue of political participation, such as Seymour Lipset (1960), Alessandro Pizzorno (1975), Robert Putnam (1977), Albert Hirschman (1985), Giovanni Sartori (1987) Wanderley Guilherme dos Santos 1989), Joseph Schumpeter (1992), Carole Pateman (1992), Leonardo Avritzer (1999), Phillipe Breton (2006) and others.

According to Pasquino (1986: 7), electoral abstention is "non-participation in voting. It can, however, be a non-participation in a set of political activities, being defined as apathy, alienation". Like many of the variables linked to electoral participation, absenteeism is easily quantitative, so it is calculated as the percentage of those who, having a right, do not appear at the polls to vote.

In most Western democracies, there have been high voter turnout rates in recent years. More democratic countries like France, USA, UK, there are great records of abstention in the elections. The French presidential elections of 2012, for example, had the highest abstention rated at $(20.52 \%)$ since 1969 , a percentage that seems modest compared to that observed in the same country in the elections to the French and European parliaments, $44.60 \%$ and $59.37 \%$, respectively (Guirardi \& Cunha, 2012). Even in Brazil, where voting is mandatory, there have been significant percentages of abstention, which competes for the perception that this phenomenon is not new to democracy.

According to Laguna (2019), electoral studies traditionally identify electoral absenteeism as the absence of the exercise of the right to active suffrage, that is, not to vote in a given electoral process. This electoral abstention, according to Laguna (2019), can have its origin in a radical discrepancy with the political regime (or even with democracy), in which one does not want to participate in any way (...) or in a conviction of that nothing can really change..

Thus, voluntary non-participation in the polls, Freire and Magalhães (2002) calls it "political abstention", which is practiced by individuals with reasonable levels of resources (material and educational) and social integration, who assume the absence on the day of the vote, as a strategic option to show their dissatisfaction with the functioning of the system and/or with the parties. Therefore, political abstention is one that expresses a refusal to existing partisan alternatives, certain political regimes and/or party leaderships.

The massive existence of electoral abstention in several democracies in the world contributes to the understanding that citizens are either tired of promises or disinterested in their participation, forgetting that this is one of the crucial phenomena for the functioning of such a democracy as is known. The abstention that occurs in the various democratic countries is a phenomenon that leads to the conclusion that it constitutes a new way of signifying political participation through silence. 
The modern state conceived by Karl Marx $(1990)^{1}$ and by Max Weber (1996) ${ }^{2}$, voting and political participation are a fundamental and inalienable right of the citizen, who in this way inaugurate a new logic of belonging to the collective and are a unifying element for the emancipation and social promotion, in the sense that the individual within society must feel free to choose his own destiny, respecting the general will as Rousseau mentioned in his great work, "the social contract".

According to Baloi (2019: 168), political participation is "a legal instrument where spaces are given for everyone to participate in the inculcation of democracy, equality of opportunity in relation to suffrage, organization of political parties and their right to stand for election".

In modern society, participating in politics and voting constitute a civic duty par excellence, a commitment of each citizen to the destinies of the community. To refuse this participation is a political immorality, since it blocks the only authorized path for the promotion of the common good (Guirardi \& Cunha, 2012).

Today, electoral abstention is the result of several factors, such as, emptying of political parties, erosion and crisis of democratic values, fragility of political and public institutions, lack of legitimacy of electoral administration bodies, lack of political culture, lack of permanent civic electoral education, among others.

According to Gaspar (1984), electoral abstention is due to voters' lack of citizenship. Large-scale citizens do not know the value of the vote and this affects their participation in the elections. The turnout has to do with the satisfaction of the aspirations that the citizens feed on the leader to be elected.

In the philosophy of existentialism of Jean Paul Sartre (2001), it is affirmed that not to choose also is a choice. In this sense, it can be inferred that abstention is also an electoral option, since it is based on free will, information and knowledge. The political change of citizens is still incipient, which may be a sign not only of political progress but also of democratic maturity.

In this sense, freedom plays a preponderant role in the exercise of democracy. To vote and not to vote is to exercise a freedom between the multiple possibilities in view of an end. "We are a freedom that chooses, but we do not choose to be free. We are condemned to freedom" (Sartre, 2001: 15).

Democracy compels a man to act as if he were persecuting himself, or seeking to fulfill himself as a citizen. Electoral absenteeism derives first from the use of political freedom, as human coexistence, from the experiences and professional and socioeconomic opportunities provided by the form of governance. Henceforth this behavior of electoral absenteeism, allows a better understanding of the democratic exercise in the relationship of citizens with political power.

\footnotetext{
1 For Marx, the conception of the state and politics are embedded in a debate about the relationship between the state and society inaugurated by modernity. Therefore, the productivist dynamics of capital and the liberalization of the individual from feudal obligations provide the basis for the formation of the contractualist conception of the modern state.

2 According to Weber, the State is considered as an institutional organization produced from social relations, which holds the legitimate monopoly of violence in a given territory, in addition to the other management functions that performs, with the rationalization and bureaucratization of government services without policymaking possibilities.
} 
According to Guirardi \& Cunha (2012), the first decades of the 21st century suggest that the perception of voting and political participation as a right, a won privilege and that guarantees citizenship, gives way to an idea that to vote and participate in policy is a duty, a burden that has been imposed by others. So if one rejects this perception which attributes to this change some kind of moral laxity of individuals (the younger generations would be alienated because they would not know, how much it cost the previous generations to gain the right to vote and political participation). Therefore, it is possible to suggest that this new position - which, still in an incipient way, is spreading in many of the western democracies points to new ways of problematizing and understanding electoral absenteeism and political participation in the so-called postmodern period.

The problems of electoral abstention have mainly started in the way citizens integrate and participate in the political system, as well as in the way they relate to political power. Democracy, as affirmed by Basílio (2015), is for the educated elite and contributes to a capacity for reflection on issues that make politics sick and improve citizens' performance in political participation. Electoral absenteeism is determined by the specific historical, political, economic, social, cultural, religious contexts to each political system that accompany them since their formation and political identity.

In Mozambique, the first municipal elections were boycotted by the largest opposition party, RENAMO 3 , and by other parties due to deficient voter registration, and indeed, by the criteria used for the selection of towns and cities that were elevated to the category of municipality. Therefore, the average flow to the polls were very low, equivalent to $15 \%$ in the country. This indicator denotes in a certain way that the non-appearance of the opposition gave advantage to the FRELIMO 4 candidates who were all elected as the presidents of all the municipalities that existed, gaining a majority of seats in the municipal Assembly in 27 of the 33 existing municipalities (BALOI, 2019: 165).

\section{Discussion}

\subsection{Municipal Electoral Abstention in Mozambique}

The process of democratization in Mozambique opened doors for the restoration of the city of Matola to the municipal statute. According to Mazula (1995), the creation of municipalities were based on the 1990 Constitution of the Republic of Mozambique and on a Law No. 2/97, of February 18, which created the legal framework for the creation of local authorities.

In accordance with Baloi (2019: 157), the institution of local authorities in Mozambique was designed to: create a well-being and improve the income and quality of life of citizens, which was achieved through local economic development; the provision of better services in

\footnotetext{
${ }^{3}$ Mozambican National Resistance, an armed movement founded in the late 1970s by André Machangaissa who opposed Frelimo's ideals and eventually sparked a 16-year civil war between 1977 and 1992. Today it is the largest opposition party with seats in the parliament.

4 Mozambique's Liberation Front is the ruling party founded in 1962 in Tanzania by Eduardo Mondlane as a revolutionary movement. This revolutionary movement united several nationalist movements and led Mozambique's liberation struggle against Portuguese colonialism. With the proclamation of National Independence on June 25, 1975, headed the leadership of the transitional government and subsequent governments, becoming a political party in 1977.
} 
each community, that this would depend on the resources generated and available in their respective communities, and to develop urban services in direct relation with the increase of municipal revenues, so that the priority would be given to the area of local development in the municipalities.

The municipality functions as a small state within a large state. It is in the municipality that the respective electorate initiates the exercise of democracy and the rights and duties of each citizen, choosing who will govern the autarchy. Municipal political power consists on proper municipal governance action desired by all citizens.

Matola city is located in the province of Maputo, in the south of Mozambique. According to Coelho (2004), the name Matola comes from the presence of the Matsolos, a Bantu origin people, which due to the migratory process and the search for better living conditions settled there, between the second and fourth centuries AD. The native ethnicity of this region are Marongas people belonging to the group of Tsongas, and the most spoken language is chiTsonga, followed by the Portuguese language.

The Matola municipality has been run since 1998 by a municipal council, executive body constituted by a president elected by direct and secret vote for a term of five years. Autarchic elections have as their fundamental objective to bring political and administrative power closer to the population and to consolidate the effective participation of citizens in public and local life.

According to STAE (1998), the first municipal elections held on June 30, 1998, in Matola, were won by Frelimo. The first president of Matola municipal council was Carlos Almerindo Filipe Tembe. These municipal elections were characterized by a level of electoral abstention in $88.4 \%$.

The second municipal elections were held on November 19, 2003, where Carlos Almerindo Filipe Tembe was elected president, with an average abstention rate of $79.4 \%$ (STAE, 2003). This second term did not end and lasted until December 20, 2007, due to the sudden death of the then mayor of this municipality. The president of Matola municipal assembly, Maria Vicente, replaced him temporarily until January 10, 2008.

The third municipal elections in Matola were held on November 19, 2008, won by FRELIMO and the elected president was Arão Nhancale with a 59.5\% abstention level (STAE, 2008). On May 15, 2013, invoking personal reasons, Arão Nhancale resigned, being replaced temporarily by António Matlhava, the then president of the municipal assembly.

In the fourth municipal elections of November 20, 2013, Calisto Cossa, a member of the Frelimo party, was elected president of the Matola municipal council, with $79.38 \%$ level of abstention (STAE, 2013).

The last municipal elections in Matola municipality took place on October 10, 2018, and the then mayor, Calisto Cossa was re-elected, with an average abstention rate of $40.84 \%$ (STAE, 2018), lowest of all time.

For Mazula et al. (1998), the experience of local elections in Mozambique shows that they contribute not only to improve the performance of municipal governance, but also to increase citizens' democratic awareness. A contractual process of political leaders towards citizens nurtures this democratic citizen awareness. It results from the understanding of the voting power to change the attitudes of political leaders and the involvement of the citizens in the autarchic governance as a form of fulfillment of the electoral promises. 
Although the elections are aimed at the active participation of citizens in political life in Matola municipality, voter turnout is still unsatisfactory due to rising levels of electoral abstention, as shown in the table and graph below.

Table 3.1. Level of Electoral Absenteeism in Matola Municipal Elections

\begin{tabular}{|l|l|l|l|l|l|l|}
\hline YEAR & \multicolumn{2}{l}{ REGISTERED } & \multicolumn{2}{l|}{ VOTING } & \multicolumn{2}{l|}{ ABSTENTION } \\
\hline & Number & $\%$ & Number & $\%$ & Number & $\%$ \\
\hline 1998 & 195274 & 100 & 22597 & 11,6 & 172677 & 88,4 \\
\hline 2003 & 263200 & 100 & 54276 & 20,6 & 208924 & 79,4 \\
\hline 2008 & 323412 & 100 & 131028 & 40,5 & 192384 & 59,5 \\
\hline 2013 & 263200 & 100 & 54276 & 20,62 & 208924 & 79,38 \\
\hline 2018 & 503459 & 100 & 297889 & 59,17 & 205570 & 40,83 \\
\hline
\end{tabular}

Source: STAE ${ }^{5}$ data $(1998 ; 2003 ; 2008 ; 2013 ; 2018)$ with author adaptations.

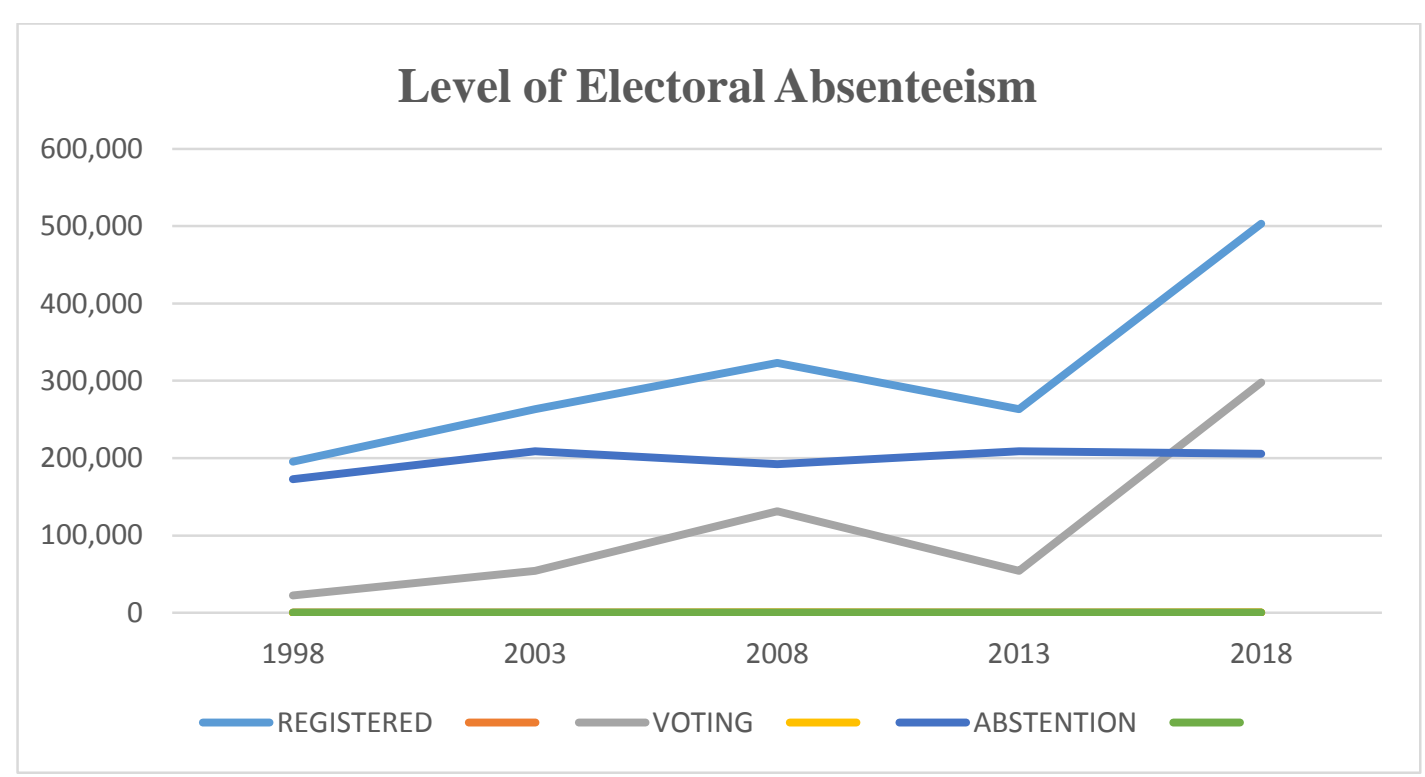

Figure 3.1. Level of Electoral Absenteeism in Matola Municipal Elections.

In general, there is no consensus on the factors of electoral abstention in Matola municipality, and in a deeper survey and in accordance with the data in the table and graph above, it can be said that the reasons that compel the residents to abstain in the choice of their representatives can be numerous. According to Ramos (2009), these behaviors of electoral absenteeism are fruits of the states of consciousness and political attitudes, which manifest themselves individually in each period of the local elections.

Therefore, voting for political alienation consists in a state of consciousness that goes beyond a mere political behavior of the individual in electoral periods, that is to say, "a disconnection of the individual in relation to the environment in which it is inserted. It is a kind

5 Technical Secretariat of Electoral Administration. 
of consciousness gap, a mental distance from the meanings of individual actions in the collective environment" (Ramos, 2009: 179).

An individual is considered alienated when he does not have a responsibility or social commitment to the community of the municipality where he lives, because voting means being committed to the development of his community and participating in its governance. Democracy is a responsibility of all citizens, which consists on participation in elections and consequently in governance.

The alienation leads the citizen to disinterest with the electoral processes and "creates an absence of identification between the candidate and the voter" (Ramos, 2009: 180). It also creates a lack of interest in the citizen to participate in the elections due to this lack of identification with political action; therefore, there is a need for an education of the citizens to the political life so that they have an effective democratic participation in the elections.

The second factor that the author advances is the apathy that the citizens present with the political electoral events, that expresses an inertia of the individual in relation to the political stimuli. "An apathetic person is indolent and indifferent, and his behavior has causes that may come from different states of consciousness or feelings" (Ramos, 2009: 183).

Apathetic individuals simply do not react to electoral acts, but follow events as a viewer. Apathy as a factor of electoral abstention manifests itself as the individual incapacity of the citizen, and consists on the feeling of social impotence. With this feeling, the citizen thinks that his vote cannot make significant changes for the development of the municipality, and objectively has affirmed that his only vote is not able to make any difference and change in the results.

Sartori (1987) explains that apathy exists precisely to demonstrate the incapacity, incompetence or disinterest of the citizens in manifesting the choice of representatives and the absence of electoral responsibility. The citizen knows that his participation will have no objective effect on the political decisions and, therefore, he ends up seeing that participating is a cost because nothing will change in his life.

Finally, the third factor of absenteeism is the electoral protest that results from the lack of confidence and dissatisfaction of the citizens with the autarchic government. Abstention can be one of the ways that residents protest with the administration and management of the municipality. Generally, the protest can be a rejection of the people by non-fulfillment of the electoral promises and denounces the social inequalities and distances between the elect and electorate.

If the individual votes or does not vote, this is only a free citizen's choice. Electoral abstention is a protest of the voter regarding to the incompetence of those who claim to be elected to the governance of the municipality. All these elements are verified in Matola municipality, because when voters abstain in the elections there is a feeling of protest that translates into absence at the polls on voting day.

The reasons for abstention in local elections are also linked to the fact that politicians tend to pursue their particular goals to the detriment of the common good of citizens. The other reason is false electoral promises, thus lacking the truth to the citizens. Therefore, the ordinary citizen continues to suffer from the poor and poor quality of public services, because of corruption and political arrogance.

It is understood that the problem of electoral abstention in Mozambique is a challenge for all political actors. According to Ngoenha (2004), democracy is a system of government that results from the free choice of rulers, through the will of the majority through voting. 
Elections are the way of the concrete freedom of peoples, even if there is still to discover or even invent new mechanisms of popular participation.

The high level of abstention in local elections results from the "lack of schooling based on civic education, on material poverty as an enemy of democracy, lack of justice and an equitable distribution of wealth" (Basílio, 2015: 197-198).

The distancing of voters from the polls results from the lack of enthusiasm of the citizens, the loss of political freedom and the lack of political alternatives. These factors are embodied in what Fukuyama (1992) considered as the emptying of the political organism characterized by individualism, which is responsible for the corrosion of democracy. On the other hand, the new technologies put at risk the forms of sociability by promoting the exaggerated individualism, diminishing the social conviviality and in turn the political participation.

According to the Mozambique Episcopal Conference (2018), abstention from municipal elections is due to the lack of confidence of local people in municipality governance. The electoral indifference of citizens is also a result of the lack of institutional power in the face of widespread problems of corruption, electoral fraud, political intolerance and disrespect for the fundamental rights of democracy, generated by the suspicion and discredit of local government, thereby compromising of voters.

However, it is understood that the chasm between the rulers of the municipality and the municipalities in general tends to increase. There is a crisis of representation in the governance of Matola municipality. The governors do not represent those by whom they were elected. Therefore, autarkic governance requires of those who have been elected, a serious desire to serve the real interests of the population of municipality.

\subsection{Causes of Absenteeism in Matola Municipality}

The first cause that contributes to electoral absenteeism in Matola Municipality is the Fragility of Political and Public Institutions. From Tollenaere's perspective (2002), electoral absenteeism has a direct influence on political parties and on their candidates for mayor's office. The fragility of political parties in assuming the role of political mobilization of the electorate in the autarky brings increasing levels of electoral abstention, which are shaped by values, political interests, the dominant attitude of citizens and the characteristics of political parties. This institutional fragility of the political parties results in part from the development of the human capacities of Matola deputies who are not accompanied by the creative innovation of the parties.

Carlos Serra (1999) considers that the great challenge of political institutions is to find sociopolitical forms and strategies that allow the citizen again to take an interest in politics. It is necessary that the institutional conditions favor the exercise of citizenship and feel that their vote has some effect. Generally, these institutions are underdeveloped due to their survival with scarce resources and inexperienced politicians and few interested in democracy.

Political institutions in general are known for not responding to the real needs of voters. Hence, voting has become unnecessary for citizens. In addition to the limited motivation of voters participation due to lack of confidence in politics, non-compliance with electoral manifestoes and satisfaction of citizens' basic needs. The Matola residents perceive the electoral act as useless and prefer not to participate in the elections.

The second vector that causes voters to abstain from going to the polls is the lack of legitimacy of the electoral administration bodies. In accordance with Mimbire (2018), when the electoral process is marked by great electoral abstention the elected ones have deficit of 
legitimacy, although according to the dictates of the legality they exercise the power. When elections generate corruption in governance, the population refrains from voting.

Thus, among democratic mechanisms, political dialogue and accountability are fundamental to democratic governance. Electoral abstention expresses innumerable factors that could jeopardize the legitimacy of democracy, and of the ruling elite, in that only a portion of the electorate participates in the elections.

The growing disrepute in the work of the electoral bodies is girded up by their incumbents, who often do not claim to be at the service of their political parties, thus forgetting that any gesture of partisanship of electoral bodies and their activities is a reason for people to stop believing at their job. This disrepute by the electoral bodies due to their party positioning has been characterized by non-acceptance of the electoral results, an attitude that ends up staining the selfless and glorious work developed by hundreds of honest professionals and frustrates millions of citizens who put their hopes in these public institutions.

According to Mozambique Episcopal Conference (2018), electoral bodies should not give in to partisan favoritism in their activities or allow themselves to be corrupted, however exalting their promises, because the cause of the common good is always greater than any type of individual commitment. Under the organic law, electoral bodies must be made up of people who are politically free of any party ideological bias. The transparency and legality, accountability and honesty of the electoral bodies will consolidate the active and participatory democracy of the citizens in electoral acts.

The third cause of electoral absenteeism is the lack of political culture of elections. The idea of political culture in this study of electoral abstention is related to the fact that it is closely linked to the socio-cultural transformations and mergers in the municipality. It is understood that this situation to a certain extent influences the electoral behavior of the citizens. According to Ramos (2009), political culture has as presuppositions the mental and communicational processes inherent in each individual and in each society, which is integrated into relational networks that support its realization as a human being. Electoral behavior must function as a living social fabric that is dynamizes and rebuilds at each electoral moment.

In this way, the concept of "political culture" appears as a factor of analysis to understand the role of the political socialization of the citizens. However, political culture is a set of acquired forms of behavior in a group of individuals, united by a common tradition, which transmits to its children and, in part, to the adult immigrants that comes to incorporate to this group.

From Reis (1991) perspective, political culture has been challenged by the heterogeneity of its social fabric. Hence, the need of promoting a social communication based on concrete actions of political achievements. Communication must be present in the characterization of the political culture of the citizens. In this sense, "political culture fosters the construction of a civic and political identity that leads to a pattern of mental, experiential, institutional, communicational and political norms inherent in the functioning of society and the state" (Reis, 1991: 58).

In addition, in order to minimize absenteeism in Matola municipal elections, it is necessary to understand the political culture as a sociopolitical behavior of citizens that derives from the relations between voters and the elect, from trust in the satisfaction of the basic needs of the citizens. These aspects are revealing of the political culture that can mold the citizens to join the polls as a privileged way in which the citizens exercises their right and duty to participate in improving the conditions of their life. It is necessary that the leaders of Matola 
autarchy run the political principle of "serving and not being served" and not using politics as the art of deceiving the majority (people) for the personal benefit of the group.

The fourth cause that contributes to electoral absenteeism is the lack of permanent civic electoral education. Civic education in elections plays an important role in the knowledge and use of opportunities for the development of their personality, for the achievement of well-being as a citizen and for the enjoyment of their civic rights. Education to politics is one of the fundamental aspects to analyze the issue of electoral abstention in local elections.

Civic education must ensure that voters can organize themselves to correctly identify their real needs and expose them to politicians who want their votes. Politicians also need civic education so that they can listen to the residents in order to know their aspirations to insert them into their governance programs. Thus, the need to include in the schools the civic-political education and participation program.

According to Brito (2003), voting is a duty of all, so no citizen should abstain from voting in municipal elections, because actually voting is governing. We must believe in politics, in active participation and in the value of the vote. Voting is a living expression of electoral behavior, which contains within it a force to trigger actions of choice that may involve party, ideological, and cultural ideological identification.

The importance of electoral education at times of the electoral campaign must be seen from both the point of view of mobilization and the essential resource at the level of electoral and political information. The elections are reflected in the set of social and cultural provisions that involve the commitment to vote. The election campaign is a time when political party programs and candidate commitments are presented to the electorate with a duty to clearly explain their proposals for future administration. It is a solemn moment of democracy in the exercise of civic rights, of the reunion and demonstration of the will to govern, of reconciliation and consolidation of the peace.

The Matola autarchy municipalities need a civic education to clarify their election choices and must contribute intelligently to the consolidation of democracy. Electoral political education is a fundamental process for social democratization and contributes greatly to minimizing electoral abstention or political indifference. A large part of the Mozambican citizens has no interest in politics. They are not participating in elections, and they are not politically deceived, in part, by ignorance of this right to vote.

\subsection{What Challenges to Electoral Abstentions in Matola Municipality?}

For the full functioning of democracy in any social context, there must be mutual tolerance and institutional reserve. "Mutual tolerance is to recognize that rivals, if they play by institutional rules, have the same right to exist, to compete for power and to rule. The institutional reservation means avoiding actions that, while respecting the letter of the law, clearly violate their spirit" (Levitsky \& Ziblatt, 2017: 8).

There are four main indicators of authoritarian behavior that could put democracy in crisis in the Mozambican context, especially in Matola municipal elections, such as: "The rejection of democratic rules of the game (or weak commitment to them); the denial of the legitimacy of political opponents; The tolerance or encouragement of violence, and the propensity to restrain the civil liberties of opponents, including the media" (Levitsky \& Ziblatti, 2017: 30-31).

Thus, the rejection of democratic rules consists on the candidates rejecting or kicking the Constitution of the Republic with a disposition to violate the norms consecrated with 
antidemocratic thoughts. This attitude of politicians is to cancel elections, restrict basic civil or political rights, and seek extra-constitutional means to change government, such as military coups, violent insurrections or mass protests to force changes in government. These elements may undermine the legitimacy of the elections by refusing the elections results.

The second principle is seen in denying the legitimacy of political opponents by considering other political actors as enemies or their rivals as a political threat, national security or the predominant way of life. This political attitude of rulers can undermine democracy with foundations of partisan rivals as criminals whose alleged violation of the law would disqualify their full participation in the political arena. This political rivalry is evident in the Mozambican context when considering opposition political parties, civil society organizations as organizations with foreign interests.

The third principle related to tolerance, encouragement of violence consists on placing links with armed gangs, paramilitary forces, militias, guerrillas or other organizations involved in unlawful violence to silence voices that are discordant with the political regime. The rulers would sponsor or encourage themselves or their supporters, a crowd attacks against opponents, and praise acts of political violence.

The last principle of the propensity to restrict civil liberties of opponents, including the media, is to provide support for laws or policies that would restrict civil liberties, such as expansions of slander and defamation laws or laws that would restrict protests and criticism of the government or certain civic or political organizations. The government would threaten to take harsh measures or other punitive actions against its critics in rival parties, in civil society or in the media.

In Mozambique, these principles are manifested attitudes of opposition politicians as well as the government of the day. For Mazula (1995), democracy comes from the passage from the stage of radical distrust to basic trust. The requirements for this democracy to manifest itself are essentially the presence of an emancipated society, where the method of dialogue and effective political participation of citizens in elections is cultivated. The emergence of multiparty democracy in any society is facilitated by the "high level of socioeconomic wellbeing, the absence of social inequalities in the face of opportunities, a high degree of social pluralism and a political culture characterized by commitment and tolerance for diversity" (Schumpeter, 1992: 193).

An effective democracy in Mozambique is possible only through a reconciliation based on the realization of the just and real promotion of the common good, the integral development of the human person, the recognition of his dignity and respect for his fundamental rights and freedoms. Over time, these fundamental principles of democracy were apparent because what is lived is indifference, apathy and lack of confidence with politics.

After many disappointments and disillusions, many Mozambicans, unfortunately have gained an aversion to everything that is political, considering it a dishonest activity, practiced by those in power to deceive the people and to carry out their personal or group interests. Those who think so, have already renounced their right (and duty) to participate in the exercise of the selection of those to whom the governance and administration of public affairs are entrusted for a certain period of time, in order to achieve the common, accessible good to all Mozambicans (Mozambique Episcopal Conference, 2018: 8).

Therefore, according to Mozambique Episcopal Conference (2018), it is a challenge for all citizens to correct the historical course of Mozambican democracy. The Matola municipality requires a special lucidity and clarity so that through electoral manifestoes and political 
ideologies they can determine the right political path capable of guaranteeing the holding of free, fair and transparent elections, as a real promotion of the common good.

Elections are marked by a high level of abstention, which, due to inexperience, can often vote badly, giving rise to blank or blank votes, frauds, intimidation, obstruction of campaign material from other political parties and promptings for various promises. The greatest democratic legitimacy of any rule of law is the participation of the population in electoral processes. "All abstention and false neutrality in the elections is a politically and historically irresponsible attitude. It would deny the duty and responsibility to contribute for the good of all" (Mozambique Episcopal Conference, 2018: 15)

Abstentions in Matola municipal elections shows that citizens' expectations of multiparty democracy are not being met, beyond the historical circumstances of democracy determined by reconciliation and consolidation of peace. This absentee behavior must be framed especially in the context of the dissatisfaction of the basic needs of the citizens and promises of deception.

Silva (2015) considers that there is no electoral transparency in Mozambique and there are also no incentives or easiness for people to vote because this process has been characterized by a penumbra that is glimpsed by successive technical failures in voter registration, fraud in the tabulation and processing of results and mistakes in requalification of null votes, favoring to the government of the day.

It is a serious challenge for voter abstention in Matola municipality, the knowledge of deceased voters after the census, and those who for various reasons have changed their usual residences. Ramos (2009) identified two essential types of abstention in elections, which are hostile and indifferent to political life. Hostile absentees are those who sees politics as something negative, and that they could be individuals with social difficulties. Indifferent absentees are those who are disinterested in political life because of their isolation and low social integration.

Another more frequent challenge is precisely the distance and the fragility of the union between elected and voters. In some way, citizens' demands for social, professional, community and religious integration are another important aspect of abstention. Voting allows a direct link between voters and elected.

In order to minimize electoral abstention in Matola municipality it is necessary that the candidates to the direction of the municipality must know the real political, social and economic problems of the municipality. They should be able to explain honestly and sincerely objectively how they will solve the real problems of society. They need to manifest the real will to serve the citizens and not be ambitious of power, wealth and interested in solving the real problems and the basic needs of the citizens.

Mazula et al (2006) argue that political culture should allow elections to be free, fair and transparent to ensure the legitimacy of rulers. People should be free to elect their real and worthy representatives without being coerced, bought or seduced. The elections are fair when all political actors have equal treatment, and are transparent when the way the electoral process has been managed or routed leaves no doubt. The elections represent a democratic political participation and illustrate a process of consolidation of democracy, reconciliation and effective peace among Mozambicans, even though elections have always been marked by conflicts, accusations, frauds and mistrust among political parties.

For Dahl (2000), democracy is a political system that offers constitutional opportunities and allows as many people as possible to participate in the main decisions through a choice 
between several alternatives. The elections are the expression of citizenship, where through the vote the citizens delegate their powers to those who will govern the autarchy.

Therefore, democracy is inherently a system of rights, which are among the essential pillars of a democratic process of government. These rights should be based on the effective participation of citizens in political life. Rights should be effectively enforced at the disposal of citizens and the promises should be translated into concrete actions to meet the basic needs of citizens.

Electoral abstentions in Matola municipality are substitutes for a total crisis of democracy characterized by the silent absence of the citizens at the polls. This disinterestedness of the citizens in the elections puts the following observation: the citizens put forward the satisfaction of basic needs as a condition of voting.

\section{Conclusion}

This article sought to analyze the problem of abstention in the local elections in Mozambique, considering Matola municipality, as the focus of analysis and it was pointed out that Mozambican democracy is still a project under construction, and should be consolidated in each electoral period through free, fair and transparent elections.

Therefore, the elections appears in the Mozambican political scene as an instrument to legitimize the multiparty democracy derived from the 1992 General Peace Agreement of Rome. They are also considered as the voice of the citizens, where they participates in the political life through the choice of leaders and political representatives, the only means to ensure effective peace, national reconciliation and socio-political stability.

This research showed that the reasons that contribute to electoral absenteeism in Matola municipality are related, among many factors, to the lack of legitimacy and transparency of the electoral administration bodies; to the fragility of political and public institutions; to the lack of political culture of elections and indeed to the lack of permanent civic electoral education.

In general, the electoral absenteeism that exists in Matola and not only, but also at the level of the country and the world is due to the fragility of electoral management bodies that are full of systemic and institutional difficulties, which make the electoral process extremely ineffective. Therefore, electoral abstention is motivated by the successive frauds and violence during the electoral campaigns, and by the lack of inclusive administration in the autarchic management.

Thus, as a minimizing measure of electoral absenteeism in Matola municipality, it is necessary that candidates for municipal management comply with the promise in their electoral manifesto. They must know the real political, social and economic problems of the municipality, and they must manifest above all a real desire to serve the citizens, creating solutions to the real problems they need.

In addition, it is necessary to create in the citizens a political culture of elections, that is to say, to create institutional conditions that favor to the exercise of citizenship. The citizens must feel that their vote has some effect on governance. This element can minimize to a certain extent the electoral absenteeism that has occurred in Matola municipality and at the country level.

This article draws the conclusion that electoral absenteeism can be a form of political questioning in order to demonstrate both the dissatisfaction and the protest that the rulers are not complying with what they have promised. However, electoral absenteeism per se is not a 
qualifying element of the disconnection of the representative power of the structuring of democracy, unless there are other forms of political questioning.

\section{References}

Avritzer, Leonardo (1999). Critical Theory and Democratic Theory: From the Impossibility of Democracy to the Concept of Public Sphere. New Studies Cebrap, São Paulo, v. 53, p. 161-187.

Baloi, Jochua Abrão (2019). The Role of Local Governments in Maintaining Democracy: An Analysis from Mozambique: Hegemony, Unieuro. Issue 26, January-June, 2019, pp. 152173. Brasília.

Basilio, Guilherme (2015). The State and the School in the Construction of the Mozambican Political Identity. Maputo, Ed. Publifix.

Bulletin of The Republic (1997). Law No. 02/97 of 18 February. Approves the Legal Framework for the Implementation of Local Authorities. I Series. Number 7. National Press: Maputo.

Bretton, Philippe (2006). The Democratic Incompetence. Loyola: São Paulo.

Brito, Luís (2003). Brief Reflection on the Autarchies, Elections, Democratization Challenges for Mozambique, Maputo.

Coelho, Vasco André Ferreira Dinis Seco (2004). (Master Dissertation) Decentralized and Participatory Cooperation between Portugal and Mozambique: The Example of Matola Municipality. Maputo.

Dahl, Robert (2000). The Democracy. Graphic Society: Braga.

Freire, André \& Magalhães, Pedro (2002), Electoral Abstention in Portugal, Social Sciences Press, Lisbon.

Fukuyama, Francis (1992). The End of History and the Last Man. Rocco: Rio de Janeiro.

Gaspar, António (1984). The Elections for the Assembly of the Republic. Damião de Góis Institute: Lisbon.

Ghirardi, José Garcez \& CUNHA, Luciana Gross (2012). The Vote of Silence: Electoral Abstention, Representations of Citizenship and Political Participation in Postmodernity. Journal of Law Mackenzie, v. 6, p. 160-169.

Hirschman, Albert O. (1985). From Consumer to Citizen: Private Activity and Participation in Public Life. Brasiliense: São Paulo.

Laguna, Juan Hernandez Bravo (2019). Active abstention. Available at: https://webs.ucm.es/info/eurotheo/diccionario/A/abstencionactiva.htm. Accessed on July 20, 2019.

Levitsky, Steven \& Ziblatt, Daniel (2017). How Democracies Die (Trad. Renato Aguiar). Zahar.

Lipset, Seymour Martin (1960). Political Man: The Social Basis of Politics. Garden City: Doubleday \& Company, Inc. New York.

Marx, Karl (1990). The 18th Brumaire of Louis Bonaparte. Mandacaru: São Paulo.

Mazula, Brazão et al (1995). Mozambique, Elections, Democracy and Development. Copyright Maputo.

Mazula, Brazão \& Gamito, Alfredo \& Macamo, Fernando (1998). Local Authorities in Mozambique, Background and Legal Regimes. Graphical press office National Casa da Moeda. Lisbon - Maputo. 
Mazula, Brazão et al (2006). Voting and Back Urns: 2004 Election Abstention. Maputo.

Mimbire, Fátima (2018). Politics and Peace. II Cycle of Conferences of the Episcopal Commission of Justice and peace. Maputo.

Mozambique Episcopal Conference (2018). Elections in Mozambique: The Catholic Church and Elections, Catholic Bishops' Pronouncements: Re-issue of Pastoral Letters, Reflective Contribution in the Framework of the Upcoming 2018/2019 Elections, Maputo.

Ngoenha, Severino Elias (2004). The Times of Philosophy: Mozambican Philosophy and Democracy. University Press: Maputo.

Pasquino, Gianfranco (1986). Dictionary of Politics. UNB: Brasilia.

Pateman, Carole (1992). Participation and Democratic Theory. Peace and Earth: Rio de Janeiro.

PIZZORNO, Alessandro (1975). Introduction to the Study of Political Participation. In: PIZZORNO, Alessandro; KAPLAN, Marcos and CASTELLS, Manuel. Participation and Social Change in Contemporary Problematics. Siap-Planteos: Buenos Aires.

Putnam, Robert D (1997). Community and Democracy: The Experience of Modern Italy. FGV: Rio de Janeiro.

Ramos, Paola Novaes (2009). Electoral Aloneness: Reflections on the Meaning of Blank Votes, Null Votes and Abstentions on Contemporary Political Theory. Mediations. v. 14, n.1, p. 170-199, Jan / Jun.

Reis, António Carlos Alkimin (1991). Electoral Participation and its Socioeconomic Correlates. In: Lima Junior, Olavo B. (Org.). Electoral System. Theory and practice. Background / IUPERJ: Rio de Janeiro.

Republic Of Mozambique (1998, 2003, 2008, 2013, 2018). Technical Secretariat for Electoral Administration (STAE). Maputo Province: Maputo.

Rousseau, J. J (2007). The Social Contract and Other Writings. Cultrix: São Paulo

Santos, Wanderley Guilherme (1989). The Dual Logic of Collective Action. Data, Rio de Janeiro, v. 32, n. 1.

Sartori, Giovanni (1987). The Theory of Democracy Revisited, volume 1. Attica: São Paulo.

Sartre, Jean Paul (2001). The Being and the Nothing: Phenomenological Ontology Essays. Vozes: Petrópolis.

Schumpeter, Joseph (1992). Capitalism, Socialism and Democracy. Jorge Zahar: Rio de Janeiro.

Serra, Carlos (1999). Incapturable Electorate. UEM- University Library: Maputo.

Silva, Carolina Rocha Da (2015). The Elections and Mozambican Democracy. Janus: Rio de Janeiro.

Tollenaere, Marc (2002). Democracy and Elections in Mozambique: Theory and Practice. In Mazula, Brazão. Mozambique: 10 Years of Peace. University Library: Maputo.

Weber, Max (1996). Science and Politics: Two Vocations. Cultrix, São Paulo. 